\title{
Banking between civil and criminal liability
}

by Michael Chan

$\mathrm{B}$ anks have traditionally walked a fine line with regard to money laundering and related compliance. On one side, under the Financial Services and Markets Act 2000, there is the possibility of breaching the laws pertaining to money laundering and the criminal sanctions that will follow and also the possibility of a regulatory action undertaken by the Financial Services Authority for failure to implement adequate money laundering prevention procedures. On the other, increasing costs leading to customer loss have been caused by overly thorough adherence to best practice for the prevention of money laundering. Walking, such a line is precarious at best but an additional hindrance to banks is that the crime of money laundering is relatively modern and has been applied with little success in the UK. Consequently, banks frequently have little to guide them when confronted with situations involving questionable clients and the possibility of money laundering.

One of the most difficult situations is the confrontation between tipping-off under section 93D of the Criminal Justice Act 1988 and a bank's ability to defend itself against a claim brought by the customer under suspicion. In such a situation, the bank may have to choose between incurring criminal liability and simply remaining defenceless to a civil suit brought by the customer. This was considered in Bank of Scotland $v$ A, The Times, 6 February 2001; judgment handed down on 18 January 2001.

\section{THE FACTS}

A was a company who was a customer of the Bank of Scotland, who had been introduced by a respectable third party. Within a couple of years of opening sterling and dollar accounts, large sums of money were being deposited in A's accounts. This alarmed the Bank of Scotland and due diligence led it to consider the possibility that the money had been obtained through Prime Bank Instrument Fraud or something similar.

Therefore, the Bank of Scotland alerted the police, the ICC Commercial Crime Bureau and the British Bankers Association. Upon alerting these parties, the Bank of Scotland became aware of investigations into activities closely associated with A. As a result, the Bank of Scotland believed that it faced a dilemma. If it paid the money out from the accounts it could be considered a constructive trustee. If it refused to pay money out, it would be subject to an action from $A$ and would be unable to defend itself, since the police had invoked section 93D of the Criminal Justice Act 1988, thus preventing the Bank of Scotland revealing the information it had received from them.

In an attempt to clarify its position, the Bank of Scotland made an application for directions, without notice and in private to Lightman J on 16 November 1999. Lightman J granted an injunction against the Bank of Scotland, restraining it from making any payments from the accounts in question. Further to this order, the solicitors to the Bank of Scotland wrote to A, stating that the bank was unhappy about certain aspects of transactions that had taken place on the accounts and that in the meantime, no further transactions of any sort could be allowed on the accounts.

A did not take any action until 21 December 1999, when it made an application to the Commercial Court. A sought an order that the sums in the accounts be paid to A's solicitors, arguing that it had an impeccable reputation and that there was no evidence to suggest that the money was tainted. At this point, A was unaware of the injunction granted by Lightman J. Indeed, when the case was brought before Gray J, he was unaware of the injunction and counsel for the Bank of Scotland was forced to inform Gray J of the order once A and their lawyers had withdrawn. After considering this, Gray J, made an order that unless an application was made by the Bank of Scotland to the court before 17 January 2000, it would have to pay the contents of A's accounts to A's solicitors.

The unfortunate effect of the proceedings in the Commercial Court was to alert A to the possibility of a criminal investigation, though they did not have any details of the investigation. Following the appearance before the Commercial Court, a series of applications were made to the court. These resulted in a variation to the order of Lightman J, allowing the Chancery proceedings to be disclosed. The Commercial Court 
proceedings were stayed by consent. In addition, the contents of the Bank of Scotland's skeleton arguments from the application to Lightman J were disclosed, as were the transcripts of the private hearings. Furthermore, the Bank of Scotland released the money in A's accounts but with the consent of all the parties froze a small sum to safeguard its ability to recover the costs that it had incurred.

Thus, when the parties appeared before Laddie J in May 2000 , the only issues that remained were as to costs and for guidance for banks as to the proper practice in the future in such circumstances. Laddie $\mathrm{J}$ found that Lightman J was wrong to grant the injunction and that it served no useful purpose, thus, he discharged the injunction. Laddie J also attempted to formulate a series of directions to assist banks in the future and awarded costs in favour of $\mathrm{A}$.

Laddie J divided his guidelines into two situations, one where the bank wished to make the payments requested by its customer, and the other where the bank did not wish to make the payments.

\section{Where the bank wishes to make the payments}

(1) If the bank wished to make the payments from the account and was aware that an investigation was taking place, it should request permission from the police to make the payment. The bank should also warn the police that the likely effect of refusal would be the issue of proceedings against the bank and the possibility of tipping off the customer that an investigation was in progress. In addition, the police might be asked to attend the proceedings brought by the customer to justify their refusal, as was suggested in $C_{V} S$ [1999] 1 WLR 1551. If the bank was refused permission to make the payment and the court was not shown any material to justify non-payment, or refused to act upon evidence that was not to be made available to the customer, the court would be likely to make an order for payment to nullify the effect the police's refusal of permission.

(2) If the police were to give permission, the bank would incur no liability under section 93A (3)(b) of the Criminal Justice Act 1988 and there would be no question of a breach of section 93D of the Criminal Justice Act 1988.

(3) If the police refused to give permission for the payment to be made but the bank still wished to make the payments, the bank should apply for a hearing in private. There, the court could require the police to appear and explain their refusal of permission. In addition, the police would be invited to state what information (if any) could be disclosed to the court and the customer in the event of the customer commencing proceedings against the bank.
(4) This would allow the court, at the end of the private hearing, to give directions as to the extent of the information that could be released by the bank if the customer brought a claim.

(5) If the police continued to refuse to allow payment from the account, the bank should refrain from making the payment, as that would constitute a criminal offence.

(6) If the customer brought proceedings against the bank, the proceedings should not be heard before the same judge who presided over the private hearing or who gave directions as to the information that could be disclosed.

(7) If the customer brought proceedings against the bank, the bank could rely upon and disclose to the customer, any information that was permitted under paragraph (3) as well as any material that the police agreed to being disclosed. If the court ordered the bank to make the payment, the bank must follow the order and it should send a copy of that order to the police. Following this court order or the order described in paragraph (3) would not constitute an offence. Any criminal proceedings to this effect would be an abuse of process as demonstrated in $C_{V} S$ [1991] 1 WLR 1551 or would be defeated by an extension of the law of necessity at common law. One should also note that payment from the account under a court order would not constitute knowing assistance.

(8) The refusal to pay the customer might alert the customer to the possibility of a criminal investigation being undertaken with respect to the account or the customer, thus, it may prejudice an investigation that is underway or that is about to be launched. However, this would not expose the bank to criminal proceedings under section 93D of the Criminal Justice Act 1988, as such a refusal would have been caused by the police's refusal to allow the payment. If a prosecution were to be brought it would be an abuse of process.

\section{Where the bank does not wish to make the payments}

Laddie J assumed that the reasons for a bank wishing not to make payments would be fear of prosecution under section 93A of the Criminal Justice Act 1988 or fear that a constructive trust exists which would render the bank liable for any sums paid out. He stated that:

(1) The bank should tell the police that they did not wish to make the payment from the account and that they feared that the customer would or already had called on the bank to make the payment. The bank should ask the police to identify any information that they would allow the bank to disclose to the court and the customer in any proceedings brought by the customer 
to enforce the payment. The bank should also inform the police that the court might ask the police to attend and justify why they refused to allow adequate disclosure. In addition, the bank should tell the police that the refusal to allow adequate disclosure would be likely to make it apparent to the customer that the reasons for refusing to make the payment were due to a serious crime inquiry.

(2) If the police allowed adequate disclosure for the purpose of the bank defending any proceedings brought by the customer, that information may be shown to court and customer without breaching section 93D of the Criminal Justice Act 1988.

(3) If the police refused to allow adequate disclosure, the bank should make an application to the court in private, inviting the police to attend and justify its position.

(4) At the end of the private hearing, the judge should be invited to decide what information the bank can disclose to the customer if proceedings are commenced. The matter of who should bear costs for the private hearing would depend upon how reasonable the bank and police have been in trying to reach a compromise.

(5) The judge who hears the proceedings brought by the customer should preferably be different to the judge who presided over the private hearing.

(6) In proceedings brought by the customer, the bank can only disclose information to the court and customer that the police have consented to being disclosed or which the judge decided should be allowed in the private hearing

(7) The bank should not bring private pre-emptive proceedings seeking to freeze the customer's account. However, if such proceedings have already been brought, they should be brought before a judge who did not preside over the private hearing. In addition, disclosure should be limited to that which the bank is permitted to disclose to the customer on any subsequent inter partes hearing.

(8) If the court orders the bank to pay the money, the bank should comply with that order and send a copy of the order to the police. Compliance with the directions of a judge which were set out at the private hearing or compliance with an order to pay will not constitute an offence as a prosecution in either situation would constitute an abuse of process or be defeated by an extension of the law of necessity at common law.

(9) Compliance with a court order for payment will not constitute breach of any constructive trust that is subsequently held to exist or knowing assistance in any breach of trust committed by the customer.

\section{THE COURT OF APPEAL}

\section{Guidelines}

The Court of Appeal did not endorse the directions of Laddie J, as they felt that the situations that could arise were so varied that it was extremely difficult to anticipate the best course of action. Nonetheless, they did state that his suggestions might be of assistance in the future. In addition, they approved of his decision that Lightman J was wrong to grant the injunction. The Court of Appeal stated that the appropriate order should have been an interim declaration under Part 25.1(1)(b) of the Civil Procedure Rules and added that such a declaration would be useful to rebut an application for summary judgment under Part 24.2 of the Civil Procedure Rules, that would be likely to result from an action against the bank by the customer.

The Court of Appeal laid down guidance but with the proviso that it was limited to what was self-evident from the present case:

(1) An injunction should never be granted in the circumstances that it was granted in the present case.

(2) If there is a dispute as to whether a payment can be made or disclosure made by the bank; the Serious Fraud Office (on behalf of the police) and the bank should attempt to resolve it amongst themselves.

(3) If no resolution can be reached, an application for interim declaratory relief should be made under Part 25 of the Civil Procedure Rules. Each party to the application should bear its own costs unless the Serious Fraud Office acts unreasonably.

(4) If proceedings are brought by a customer of the bank, the bank will have to reach a commercial decision as to whether to contest to proceedings or not. If they are to be contested, this should be done in as open a manner as possible.

(5) In certain circumstances it may be best for the same judge to preside over the Part 25 application and any proceedings against the bank. If this occurs and there are proceedings of which a bank's customer is unaware, then there will be no question of the bank being subject to criminal proceedings if it acts in accordance with the guidance of the court.

\section{Constructive Trusts}

One point of contention that the Court of Appeal felt it should comment on was the claim of constructive trusteeship by the Bank of Scotland. This was the basis for their application to Lightman J and was attacked by A's counsel. The Court of Appeal acknowledged that the bank-customer was a commercial relationship, rather than a fiduciary one, citing Foskett v McKeown [2000] 2 WLR 1299. However, it also accepted that it was possible 
for a bank to become subject in equity to an accessory liability if it dishonestly assisted a breach of trust committed by the customer or others. After considering a number of cases including Manchester Trust $v$ Furness [1895] 2 QB 539, Foley v Hill (1848) 2 HLC 28, Selangor United Rubber States v Craddock (No 3) [1968] 1 WLR 1555, Royal Brunei Airlines v Tan [1995] 2 AC 378, El Ajou v Dollar Land Holdings [1993] 3 All ER 717 and Finers v Miro [1991] 1 WLR 35, the Court of Appeal suggested that the Bank of Scotland would be allowed to seek directions "on the footing that it was at least a putative fiduciary". The reason provided for this was:

'...there was a clear risk of the bank incurring liability in equity as an accessory to breach of trust. A bank placed in that dilemma ought to be able to invoke equity's assistance. The fact that the bank was not formally constituted as a trustee and that a tracing process would attach, not to any assets of the bank, but to the chose in action representing the bank's obligation to its customer, ought not to be an insuperable obstacle...'.

Neuberger $\mathrm{J}$ appeared to have found a method of overcoming this obstacle by requiring the balance of the account to be treated as if it had been paid into court. However, the Court of Appeal did not wish to encourage this.

\section{Costs}

The Court of Appeal also approved Laddie J's decision to award costs against the Bank of Scotland, stating that the nature of the bank's business made it more appropriate for it to bear the costs of the defendants, than vice-versa. This is a rather bitter pill for a bank to swallow, since its attempts to co-operate with the authorities may lead it to litigation for which it will have to bear the costs. However, it may be possible to consider this as the price to pay for a perception of probity and the possibility of avoiding heavier regulation in the future.

\section{CONCLUSION}

This case provides welcome advice to banks that find themselves torn between tipping off a client and being held as a putative fiduciary. The advice provided by the Court of Appeal appears to be relatively simple in that negotiation should take place between the Serious Fraud Office and the bank involved before any court applications are made, as well as clarifying that an interim declaration should be sought rather than an injunction. However, it remains to be seen how readily the Serious Fraud Office will permit the release of sufficient information for a bank to defend itself. This is the crux of the matter, since the premature release of too much information by the Serious Fraud Office and NCIS could result in the loss of a chance to obtain a successful conviction. Meanwhile, if they err on the side of caution, the likely and unsatisfactory result would be an appearance before the courts at the probable expense of the bank.
Perhaps what is most heartening is the willingness shown by the Court of Appeal to assist financial institutions that are attempting to co-operate with the authorities by suggesting that the same judge preside over a Part 25 application and any other proceedings. This would allow proceedings to progress at a quicker pace, which would be beneficial for all parties in terms of time, resources and costs. In addition, it would ensure that the bank avoids any criminal liability as long as it acts in accordance with the declaration granted as well as avoiding any equitable liability.
Michael Chan

IALS 